\title{
The Effect of Land Use Systems on Soil Properties; A case study from Rwanda
}

\author{
Theobald Bizuhoraho ${ }^{1}$, Alexis Kayiranga ${ }^{2}$, Noel Manirakiza ${ }^{3} \&$ Khaldoon A. Mourad $^{4}$ \\ ${ }^{1}$ Pan African University, Institute of Water and Energy Sciences, Algeria \\ ${ }^{2}$ University of Rwanda-College of Agriculture, Animal Sciences and Veterinary Medicine, Rwanda \\ ${ }^{3}$ Selçuk University, Konya, Turkey \\ ${ }^{4}$ Center for Middle Eastern Studies, Lund University, Lund, Sweden \\ Correspondence: Khaldoon A. Mourad, Center for Middle Eastern Studies, Lund University, Lund, Sweden. \\ E-mail: Khaldoon.Mourad@cme.lu.se
}

\author{
Received: November 15, 2017 Accepted: December 1, 2017 Online Published: January 30, 2018 \\ doi:10.5539/sar.v7n2p30 \\ URL: https://doi.org/10.5539/sar.v7n2p30
}

\begin{abstract}
Land use change has a significant impact on the ecosystem. In this paper the effects of land use change on the physicochemical properties of the soil in Rulindo District, Rwanda have been studied. Three different land use types were selected; forestland, cattle farmland and cultivated land. A randomised complete block research design was used to carry out this research. Nine soil samples were collected and then analysed. The distributed samples were analysed in the Soil Laboratory of University of Rwanda-Busogo campus, while the undisturbed samples were analysed in-situ. Eight physicochemical properties were measured: pH, Organic Matter (OM), available nitrogen, available phosphorus, exchangeable potassium, soil bulk density, moisture content and porosity. The results showed that changing land use from forest or farm to cultivated land reduced the organic matter, available nitrogen, soil moisture and porosity while bulk density and $\mathrm{pH}$ were significantly increasing. On the other hand, the exchangeable potassium and exchangeable phosphorus did not change significantly for the both land use changes. Hence, the reduction of forestland and farmland are highly sensible to erosion and will decline soil fertility. The paper proposed few steps and recommendations to be the base for a new sustainable land use management in Rwanda.
\end{abstract}

Keywords: forestland, farmland, cultivated land, sustainable land use management.

\section{Introduction}

Changing land use from forests to croplands leads to a change in the chemical, physical and biological properties of the soil (Houghton et al., 1999; Zhang et al. 2004; Viollete et al., 2009). Anthropogenic activities are changing the Earth's surface hence they change the physicochemical properties of the soil, its structure and reduce soil fertility. Deforestation increases soil erosion because of the reduction of the soil stability, which leads to floods, drought and natural ecosystem degradation (Arévalo et al., 2015). Land use change to cropland have changed significantly from the twentieth century, it is estimated that $25 \%$ of the Earth's surface will be occupied by cropland, shifting cultivation and livestock production in the twenty first century. Globally the decreasing rate of forests was about $1.7 \%$ in the period of 1990 to 2005, especially in Africa where 1.6 million hectares of forest areas were lost per year (FAO \& JRC, 2012).

Rwanda has mountainous land, mostly located in the northern part of the country where Rulindo district is located, characterised by high rainfall and cool climate. Land use change from forested land into arable land showed a significant increase where over 880 and $1150 \mathrm{~km}^{2}$ of forest area converted into cultivated land use in 1992 and 2014, respectively (FAO, 2016). The population of Rwanda is highly increasing, currently the population density estimates to 468 inhabitants $/ \mathrm{km}^{2} .80 \%$ of the Rwandan populations depends on agricultural activities (NISR, 2012). However, available arable lands are below FAO standard, 0.9 ha/inhabitants, to meet economic viability (FAO, 2016).

Runoff from steep hills, combined with high population growth, increasing of the agriculture land, deforestation, soil erosion and flooding are the main land use challenges in Rulindo District (FAO, 2017). Therefore, lands in Rwanda are under a high pressure of utilisation through the converting rates of forestland and pastureland into 
cropland. Short-term land fallowing and deforestation increase soil losses, decline soil fertility, and increase land degradation, especially in highlands with slope up to $80 \%$, mostly located in Buberuka region in Rulindo district (Clay et al., 1996; Kagabo et al, 2013). Overexploitation of land in Rwanda and the poor land management increased soil loss due to soil erosion, which ranged from 2.6 tons/ha/year up to 41.5 tons/ha/year between 1996 and 2013, respectively (Byiringiro, 1996; Nabahungu, 2013). The severe soil erosion and the poor land management have also increased the total annual losses of chemical soil properties. The annual estimated losses were 945,200 tons of organic matter, 41,210 tons of Nitrogen and phosphorus and 3,055 tons of potassium (Nabahungu, 2013). Over 50\% of the natural forests in Rwanda have been lost over the last 40 years, mostly due to the expansion of arable land (Twagiramungu, 2006; FAO, 2016).

Rwanda is one of the African countries that are committed to achieve SDGs by 2030 especially Goal no. 15 , to protect, restore and promote sustainable use of terrestrial ecosystems, sustainably, manage forests, combat desertification and halt, reverse land degradation, and halt biodiversity loss. Specific goals 15.2 and 15.5 are aiming to promote the activities of sustainable forest management and taking significant actions to reduce the degradation of habitats ecosystem by 2020 (FAO, 2016).

It is very important to study the impact of land use change on physicochemical properties, which can help policy makers and different stakeholders to have a proper land use planning aiming at replenishing soil fertility, protecting forests and restoring the degraded ecosystem. This paper aimed at highlighting the effects of land use change on the socioeconomic condition and the ecosystem in Rwanda to encourage stakeholders and decision makers to make actions in this regard. The research proposed steps and recommendations that can be the base for future sustainable plans in Rwanda. The paper compared the effects of land use change on physicochemical properties of soil in Rusiga sector by studying $\mathrm{pH}$; organic matter content (OM); total nitrogen (TN); available phosphorus (AP); exchangeable potassium (EP); moisture content (MC); bulk density (BD) and porosity (P) of the three selected land use systems; forestland, farmland and cultivated land. Then, the paper proposed few steps and recommendations to be the base for a new sustainable land use management in Rwanda.

\section{Materials and Methods}

\subsection{Study Area Description}

This research was conducted in Rusiga sector, Rulindo District Fig. 1, about 27 km from the capital city Kigali toward Musanze City in Northern Province. The climate of Rulindo District is characterised by tropical climate with and average rainfall about $1240 \mathrm{~mm} /$ year, distributed in two-rainy seasons. The minimum temperature is $19^{\circ} \mathrm{c}$ while the highest temperature is $28^{\circ} \mathrm{c}$. Land of Rulindo district is characterised by high steep hill of height up to $2,438 \mathrm{~m}$ with mostly clay and clay loam soils dominant. Agriculture is one of the widely engaged economic activities of Rolando's people (Rulindo DDP, 2013). 


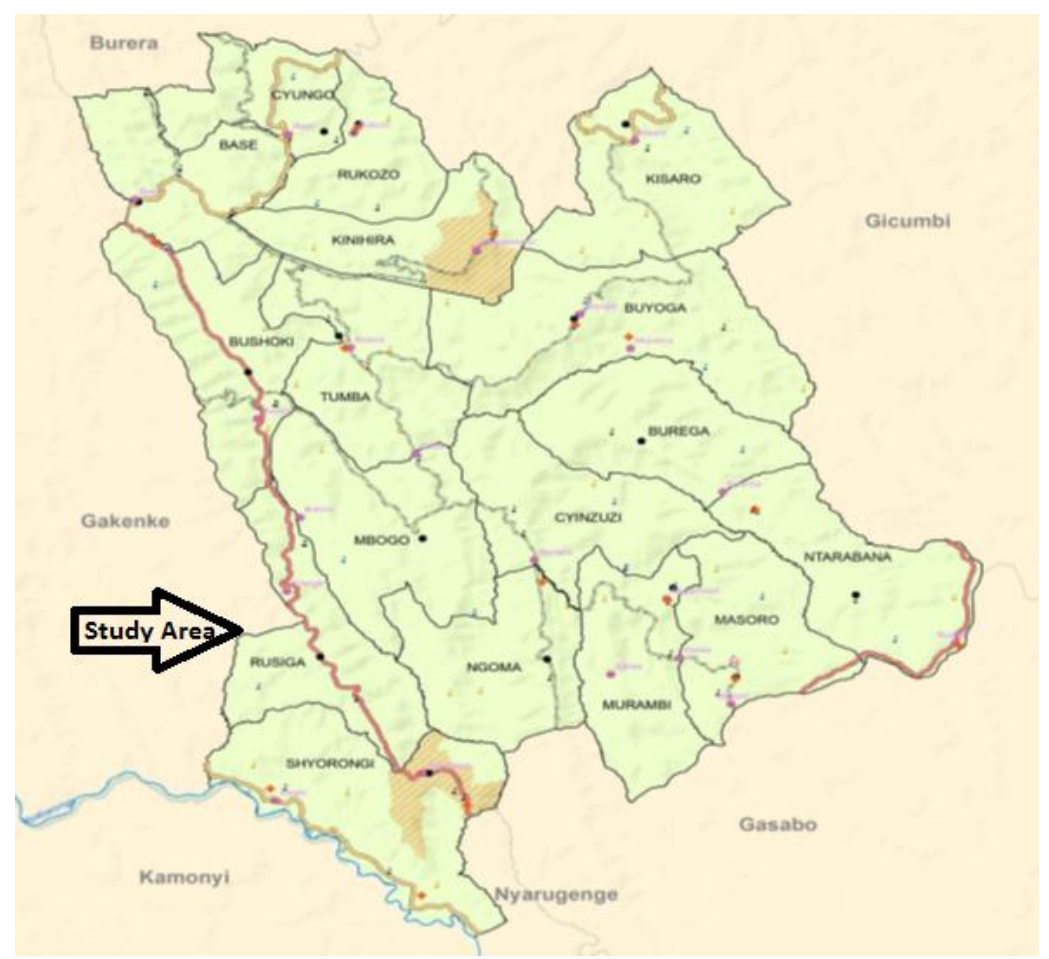

Figure 1. The geographical map of Rulindo district (NISR, 2012)

\subsection{Soil Sampling}

A randomised complete block research design used for collecting soil samples in the three representatives land use selected: Forestland, farmland and cultivated land. During the collection of the samples, the dead plants, furrow, old manure, wet spots, areas near of the trees and compost pits were avoided for reducing errors that can occur during analysis as well as minimizing differences in results that may come from the addition of organic matter into the soil. Nine soil samples were collected. The disturbed soil samples were collected at an average soil depth of $0-30 \mathrm{~cm}$ using Hand Soil Auger whereas the undisturbed soil samples were collected using Core Cylinder in 2015. The collected disturbed and undisturbed soil samples were analysed in the soil laboratory of University of Rwanda-Busogo campus. The disturbed soil samples were dried at room temperature, passed through a 2-mm sieve diameter to remove stones, roots and large particles. The chemical properties of the sieved disturbed soil samples were analysed including $\mathrm{pH}, \mathrm{OM}$, AN, AP, and EP; while the undisturbed soil samples were used for determining in situ the physical properties: MC, BD and P.

\subsection{Soil Samples Analysis Details}

pH: pH-meter with a glass electrode in a soil-water suspension using a 1:2.5 soil/water ratio was used for determining soil $\mathrm{pH}$. During the analysis, $10 \mathrm{~g}$ of soil sample sieved at a $2 \mathrm{~mm}$ diameter sieve, weighed and then put in a well-cleaned bottle. The distilled water poured into the bottle with 1:2.5 soil/water ratios. The closed bottle placed on agitator at 300 rounds per second for 15 minutes. The agitated solution left to settle for around 30 minutes. Then, the $\mathrm{pH}$ value was recorded.

Organic Matter Content (OM): Calcination method was used to determine the soil organic matter according to Armo et al. (2012). During the laboratory analysis, the crucibles were dried at $105^{\circ} \mathrm{c}$ for one hour. Hence, $2 \mathrm{~g}$ of the soil samples were sieved at $0.5 \mathrm{~mm}$, then added into the dried crucible. Then the mass was recorded. The crucible containing soil sample was dried in an oven dryer at $105^{\circ} \mathrm{c}$ for three hours, then the mass (M1) was recorded. This process was repeated but the crucible contained soil sample dried into furnace at $450^{\circ} \mathrm{c}$ for three hours and its mass (M2) was recorded. Finally, OM was calculated using the following equation:

$$
\% O M=\frac{(M 1-M 2) g}{2 g} 100
$$

Available Phosphorus (AP): The available phosphorus was determined using Bray 2 method a cording to Bartlett et al. (1994) where a $5 \mathrm{~g}$ sample of the soil samples was sieved at a $2-\mathrm{mm}$ sieve and then was put in a testing tube. Then $33 \mathrm{ml}$ of the extracting solution Bray 2 was poured in the testing tube containing soil sample 
and mixed for 5 minutes. The mixture was filtrated using filter paper. Finally, the filtered solution was put in the Atomic Adsorption Spectrometer (AAS) that automatically read the phosphorus content. The available Phosphorus calculated using the following equation:

$$
A P=\text { Reading data in } A A S * 35 / 5
$$

Exchangeable Potassium (EP): The exchangeable potassium was estimated using the Cobalt Nitrite method after being percolated by ammonium acetate (Brady et al. 2002). During the analysis, $5 \mathrm{~g}$ of the soil sample was weighed and poured in a test tube. Then $33 \mathrm{ml}$ of $\mathrm{N}$ of ammonium acetate solution was poured on top of it and both were mixed together in the test tube for 5 minutes. Then the solution was filtered, and the extracted solution was put in the Atomic Adsorption Spectrometer (AAS) that determined automatically the amount of potassium.

Total Nitrogen (TN): Total nitrogen was determined using Kjeldahl method (Benton, 1991). Kjeldahl method involves three steps: mineralisation, distillation and titration. Mineralization aims at changing the solution into minerals. We poured mineral organic matter and sulphuric acid with catalyst to the soil sample. The solution heated for 2 hours on a $300^{\circ} \mathrm{c}$ oven until the green colour appeared. Distillation aims at getting vapour condensation. After preparing of the distillation flask, $10 \mathrm{ml}$ of sodium hydroxide and $10 \mathrm{ml}$ of sulphuric acid were added into the mineralized solution. By evaporation, the nitrate solution collected in $5 \mathrm{ml}$ of boric acid. Titration aims at getting the amount of Nitrogen. The distillate solution contained excess acid was titrated by sodium hydroxide until pink colour appeared as endpoint. The colour changed from green to pink then yellow. Then, the used volume of sodium hydroxide, to nearest $0.01 \mathrm{ml}$ of concentration, was recorded.

Moisture Content (MC): The moisture content was determined using gravimetric method (Black, 2005) where $10 \mathrm{~g}$ of wet undisturbed soil sample was weighed (M1). Then the weighed sample was placed in an oven dryer at $105^{\circ} \mathrm{c}$ for 3 hours and its mass (M2). Finally, the percentage of soil moisture content obtained by:

$$
\% S M C=((M 2-M 1) g) * 100 / 10 g
$$

Bulk Density (BD): The bulk density was determined using core method. We weighed the volume of core cylinder $(\mathrm{V})$ contained undisturbed sample before taking the samples on the field. After taking the samples, we weighed the mass of the core cylinder and soil sample (M1). Then we heated the core cylinder containing soil sample in an oven dryer at $105^{\circ} \mathrm{c}$ for 3 hours and record the mass (M2). Bulk density was determined by:

$$
B D=\frac{M 2-M 1}{V}
$$

Porosity (P): The porosity was determined using the equation taking where particle density (PD) equals 2.65:

$$
P=(1-B D / P D) * 100
$$

\subsection{Statistical Analysis}

The analysed data kept in a Microsoft Excel file and later, the analysis of variance (ANOVA) was conducted on the collected data to check the differences between the three selected land uses using the $14^{\text {th }}$ Edition of the GenStat software. The overall significance of land uses was evaluated by applying LSD test on a grand mean data at the $5 \%$ level of probability $(\mathrm{p} \leq 0.05)$ based on the F-test of the analysis of variance. In addition, the value of each analysed parameter, was compared to the norms and interpretation of the Mutwewingabo and Rutunga (1987) for characterizing the soil of Rusiga sector.

\section{Results and Discussion}

\subsection{Land Use Change Effects on Chemical Soil Properties}

Soil pH: The highest soil $\mathrm{pH}$ was found in the cultivated land with a $\mathrm{pH}$ value of 5.3 , while, the lowest $\mathrm{pH}$ was found in forestland with a pH value of 4, Fig. 2. The acidic condition of the cultivated land was high due to the intense parent materials weathering, lime application, organic and inorganic fertilizer applications by the farmers. The application of poultry manure alone or in combination with wheat straw residues and urea gave a significant increase in $\mathrm{pH}$, while urea $\mathrm{N}$ and wheat straw residues tended to decline $\mathrm{pH}$ showing acidifying effect on soil (Abdul et al., 2014). Previous studies showed that the application of poultry manure and farmyard manure increased soil $\mathrm{pH}$ (Abbasi, \& Tahir, 2012). The higher $\mathrm{pH}$ in poultry manure amended soil is probably due to the 
release of $\mathrm{OH}^{-}$ions during decomposition of manure and the buffering from organic compounds released from manure ( Zingore et al., 2008; Azeez et al., 2010). Also compost without or with NPK fertilizer application have significantly increased soil $\mathrm{pH}$, while mineral $\mathrm{N}$ fertilizers revealed a significant decrease in soil $\mathrm{pH}$. The soil became acidic due to higher exchangeable $\mathrm{Al}^{3+}$ and $\mathrm{Fe}^{3+}$ contents (Bucagu et al., 2013). Organic amendments particularly organic manures revealed liming effect that increased soil $\mathrm{pH}$ while the $\mathrm{NH}^{4+}$ in mineral fertilizers had acidifying effect that declined $\mathrm{pH}$. The acidic cations caused leaching of basic cations and formations of insoluble salt that led to reduction in basic cations.

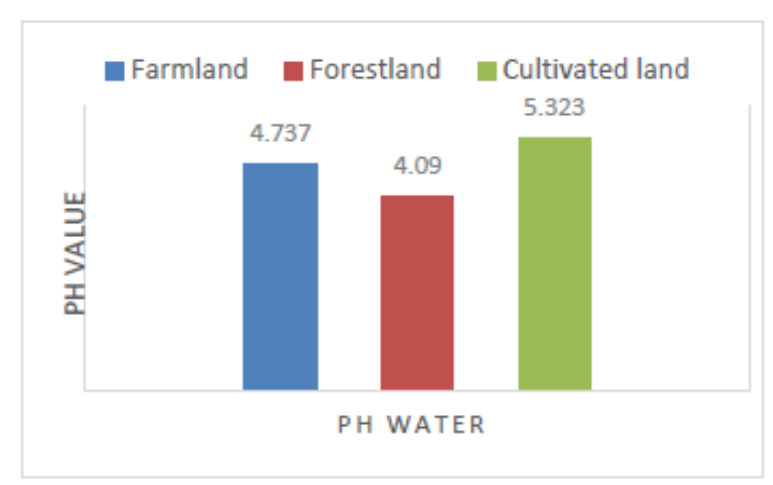

Figure 2. Effect of land use change on soil pH

In addition, decreasing $\mathrm{pH}$ values $(<5.5)$ is due to the increase of $\mathrm{Mn}$ and $\mathrm{Zn}$. According to the norms and interpretation of Mutwewingabo and Rutunga (1987), soil pH of Rusiga sector was varying from strong acidic to fair acidic soil.

Organic matter (OM): According to Mutwewingabo and Rutunga (1987), the norms and standards of interpretation for soil organic matter, OM content of Rusiga sector was ranging from humic to high humic organic matter. Analysis of variance revealed that $\mathrm{OM}$ was significantly affected at $\mathrm{p} \leq 0.05$ by different land use change (Table1). The highest OM content was found in the forestland, while the lowest OM content was found in the cultivated land, Fig. 3. In the forestland tree leaves, stems, barks, flowers, logs and fruits increase OM. İt was also reported earlier that the addition of organic amendments had increased humus contents, which may result more $\mathrm{C}$ into soil $\mathrm{C}$ pool (Panwar et al., 2010). In addition, microorganisms, animals and trees roots contribute to the increase of OM (Osman, 2013). Organic matter can be considered as the best amendment for most soils due to its increase in water retention capacity and physical properties improvement of soils (Karimi et al., 2007). On the other hand, the cultivated land use had low OM content comparing to the other land use due to the cultivation practices that increased soil aeration, which increases OM decomposition (Kizilkaya, 2010).

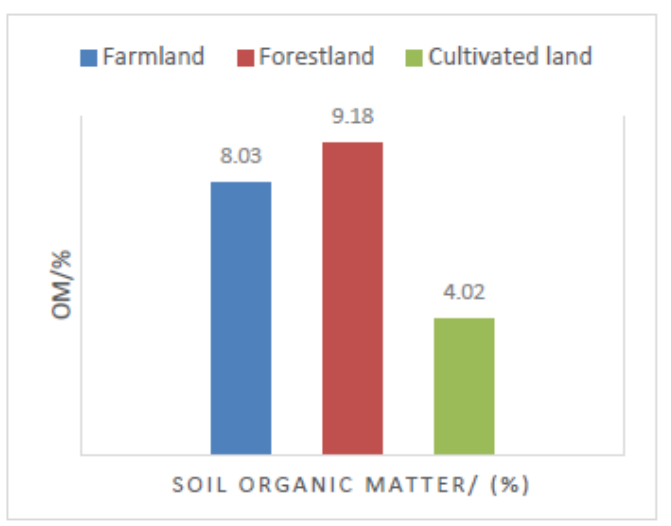

Figure 3. The effect of land use changes on SOM

Total Nitrogen (TN): According to the norms and interpretation of Mutwewingabo and Rutunga (1987), the TN of Rusiga sector was ranging from middle to high TN class. Analysis of variance showed that TN was significantly affected $(\mathrm{p} \leq 0.05)$ by different land use change (Table1). The results of TN obtained in this study, showed that there was a significance difference between the selected land uses. TN found in the farmland was high relatively to other land uses. The highest TN found in the farmland with an average range of values of 0.6 
meq/100g, followed by forestland with TN value of $0.537 \mathrm{meq} / 100 \mathrm{~g}$ and finally the cultivated land use had TN value of $0.390 \mathrm{meq} / 100 \mathrm{~g}$, Fig. 4. It has been reported that the organic/inorganic amendments or their combination application has significantly increased TN (Abdul, \& Abbasi, 2014). The reduction of TN in cultivated lands may due to the high value of $\mathrm{C} / \mathrm{N}$ ratio and mineralisation of $\mathrm{OM}$, hence the nitrogen content led to the immobilisation by microorganisms (Koth, 1990). In addition, the tillage practises reduced soil nitrogen content by exposing the soil to more air that bacteria need, comparing to non-tillage soil.

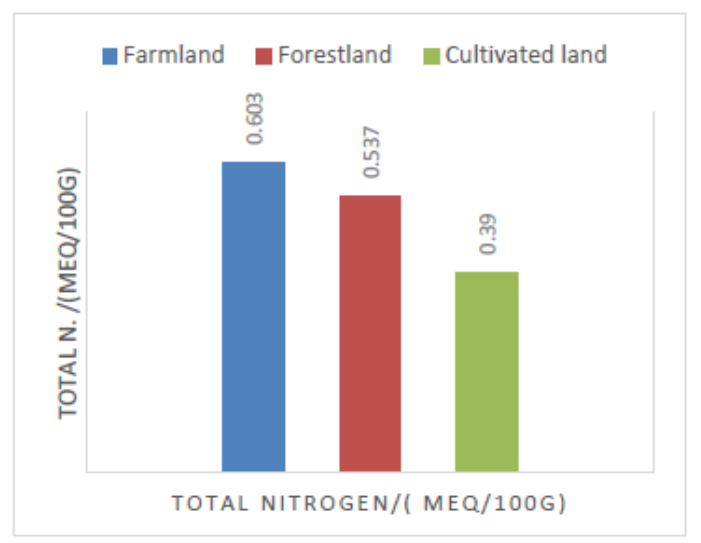

Figure 4. The effect of land use changes on TN

Available Phosphorus (AP): According to the norms and interpretation of Mutwewingabo and Rutunga (1987), the soil of Rusiga sector was located in the same class of high phosphorus content. According to the analysis, the highest AP was found in the farmland with value of $84 \mathrm{ppm}$, followed by cultivated land with value of $76 \mathrm{ppm}$ and finally the lowest AP was found in the forested land with a value of $70 \mathrm{ppm}$, Fig. 5. The low pH values of the forestland, comparing to other land uses, can facilitate the exchangeable aluminium, iron hazards and the fixation of phosphorus as different precipitates, hence the farmland has low value of AP comparing to other land uses (Hansson et al., 2011). The application of organic and inorganic fertilizers plays an important role in increasing AP. İt has been reported that poultry manure alone or in combination with wheat, straw residues (WSR) and urea N (UN) have significantly increased AP throughout the study. Similarly, combination of UN and WSR has significantly increased AP compared to their sole application (Abdul, \& Abbasi, 2014).

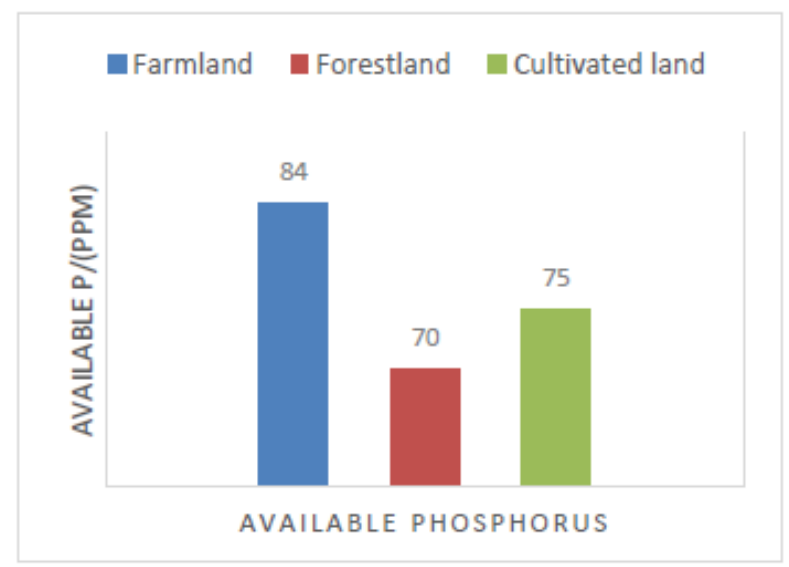

Figure 5. The effect of land use changes on AP.

Exchangeable Potassium (EP): Results showed that there is no significant difference between land uses. Forestland and cultivated land were having the same value of EP of $0.3533 \mathrm{cmol}+\mathrm{kg}$, while it was was $0.3333 \mathrm{cmol}+/ \mathrm{kg}$ in farmland, Fig. 6. An earlier study showed that greater AP was found in organic amended soils compared to systems receiving mineral fertilizers alone (Panwar et al., 2010). 


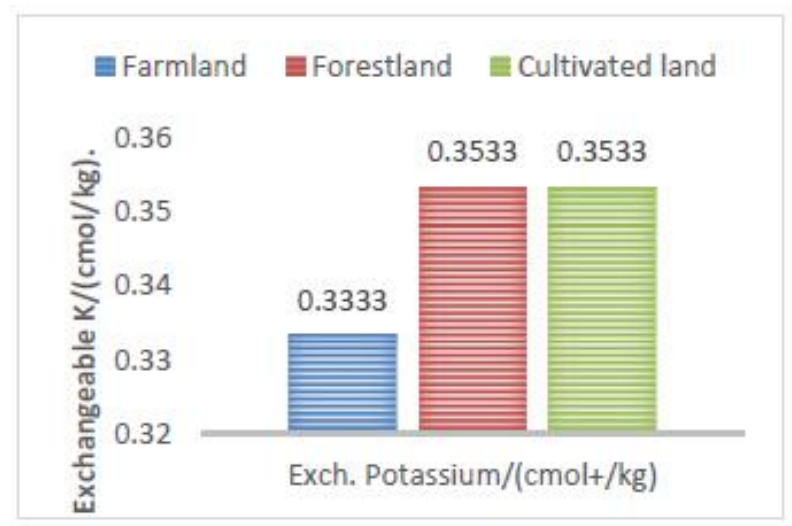

Figure 6. The effect of land use changes on EP

Table 1. Effect of land use system on soil chemical properties of Rulindo District, Rwanda

\begin{tabular}{lccccc}
\hline & $\mathrm{pH}$ & $\mathrm{OM}(\%)$ & $\mathrm{TN} \mathrm{meq} / 100 \mathrm{~g}$ & $\mathrm{AP} \mathrm{ppm}$ & $\mathrm{EP} \mathrm{cmol} / \mathrm{kg}$ \\
\hline Farmland & 4.74 & 8.03 & 0.603 & 84 & 0.333 \\
Forestland & 4.1 & 9.18 & 0.537 & 70 & 0.353 \\
Cultivated land & 5.3 & 4.02 & 0.39 & 75 & 0.353 \\
P $<0.05$ & 0.0 & 0.01 & 0.042 & 0.89 & 0.171 \\
LSD & 0.4 & 3.11 & 0.382 & 70.3 & 0.026 \\
\hline
\end{tabular}

\subsection{Land Use Change Effects on Physical Properties of Soil}

Bulk Density (BD): Analysis of variance showed that BD had no significant difference at $\mathrm{p} \leq 0.05$ by different land use change (Table2). The highest BD value was found in cultivated land use with $1.617 \mathrm{~g} / \mathrm{cm}^{3}$, while, the lowest BD was found in the forestland use with $0.983 \mathrm{~g} / \mathrm{cm}^{3}$, Fig. 7. The decrease in the BD might be related to the accumulation of higher organic matter from the added organic amendments. Soils amended with organic or inorganic amendments showed a reduction in BD (Abbasi \& Tahir, 2012; Abbasi et al., 2010; Bandyopadhyay et al., 2010). The decrease in BD was due to the higher organic matter content, better soil aggregate, better least limiting water range and increased root growth with lower cone penetration resistance and bio pores due to high organic matter content (Bandyopadhyay et al., 2010). A well aggregated soil, loose and porous have high organic matter and lower bulk density while poorly aggregated soil has low organic matter content and high bulk density that make total pore spaces become greater (USDA, 2017). As the soil organic matter was increasing from forestland to farmland to cultivated land, consequently the ratio of bulk density should be the opposite. By using the interpretation norms of Mutwewingabo and Rutunga (1987), the soil found in the studied land use types was ranging from good to moderate bulk density.

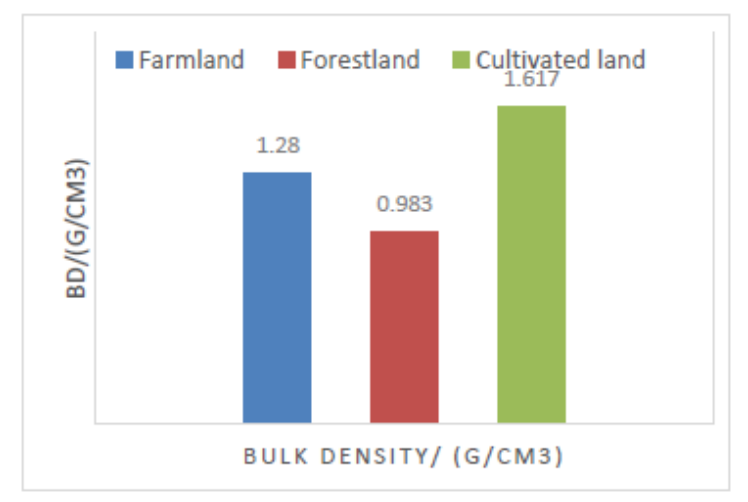

Figure 7. The effect of land use changes on BD

Moisture Content (MC): Results showed that the highest value of MC was found in farmland with $25.24 \%$, followed by forestland with MC value of $17.36 \%$, while the lowest MC was found in the cultivated land with MC value of $16.93 \%$, Fig. 8, which was due to sunshine and tillage practises, which increased pores and 
evaporation. Due to the fact that the energy enters easily in cultivated land use, soil becomes dry and soil moisture content decreases comparing to the other land uses (Drago et al., 2015). Comparing the results of this study with the norms and interpretation of Mutwewingabo and Rutunga (1987), the soil moisture of all selected land uses was moderate moisture content.

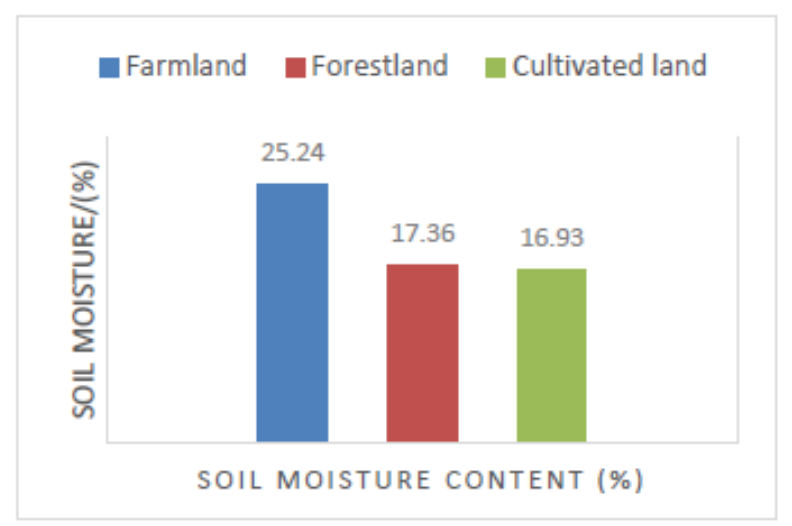

Figure 8. The effect of land use changes on SMC

Porosity (P): Soil porosity is the total number of pores and open space between soil particles. The highest $\mathrm{P}$ was found in forestland with $\mathrm{P}$ value of $62.9 \%$, followed by the farmland with $\mathrm{P}$ value of $51.7 \%$, while the lowest $\mathrm{P}$ was found in cultivated land with $\mathrm{P}$ value of $39 \%$, Fig. 9. P was high in forestland use relatively to other land use due to the high organic matter content and earthworms that play an important role in the decomposition of organic material. It has been reported that the decrease in bulk density with organic amendments is directly related to the increased porosity, which is related to the improved soil aggregation (Guidi et al., 1984). In addition, pore spaces are increasing by the movements of the grass roots hence increase the voids between soil particles. The values of soil porosity of these land uses were ranging from bad soil porosity to very good soil porosity.

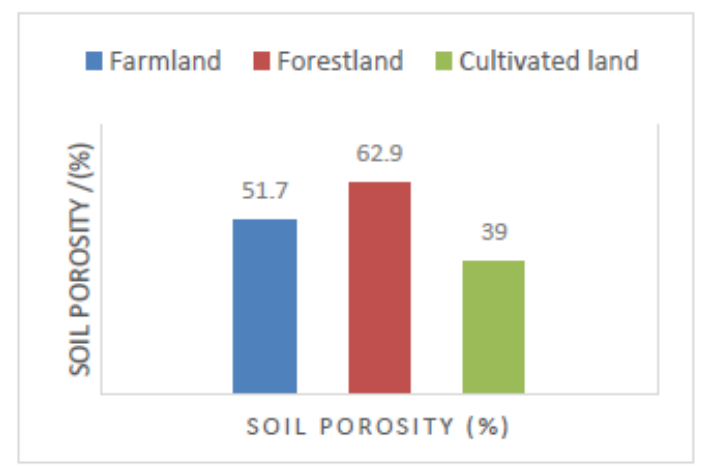

Figure 9. The effect of land use changes on SP

Table 2 shows the statistical analysis of the effect of the land use systems on the physical properties of the soil in Rulindo District.

Table 2. The effect of land use system on soil physical properties

\begin{tabular}{llll}
\hline & $\mathrm{BD}\left(\mathrm{g} / \mathrm{cm}^{3}\right)$ & $\mathrm{MC}(\%)$ & $\mathrm{P}(\%)$ \\
\hline Farmland & 1.280 & 25.24 & 51.7 \\
Forestland & 0.983 & 17.36 & 62.9 \\
Cultivated land & 1.617 & 16.93 & 39.0 \\
$\mathrm{P}<0.05$ & 0.084 & 0.004 & 0.084 \\
LSD & 0.5595 & 3.992 & 21.11 \\
\hline
\end{tabular}


A sustainable land use management is the use of land to meet human needs either agriculture, forestry, construction or other social needs practiced on land with the aim of ensuring long-term and future socioeconomic, ecological and environmental functions of people of future generation (Smith et al., 1993; Masozera et al., 2004). Together with SDGs goal no. 15, the following actions at national level, sector level and village level together with the engagement of the stakeholders in land use management can improve land management. However, much emphasis should be put on village as it is the smallest unit, which is the base of the land use management success.

National Level: On the national level, Rwanda needs an institution that will be in charge of land use management, Land Use Management Institute LUMI. Land use management should be based on national norms and policies by which the LUMI can have some of the following missions: assessing all land use activities, protecting land use from illegal change practices, studying the expected risks, setting monitoring programs, raising public awareness, and setting local land use centres at all provinces. The establishment of the policy regarding to land use and complying with other institutions with sectorial wide approaches is also required. LUMI will comply with other institutions to propose policies and strategies aiming at food production on small land available, renewable energy use, and protecting the environment and ecosystem. This will reduce the rate of improper expansion of cultivated land and farmland use in Rwanda. At national level also, research projects, actions and funds for land use management are needed to restore the degraded land and to provide incentives to create agroforestry trees nurseries all over the country.

Sector level: The allocation of enough funds for actions and activities that are related to the sustainable land use management is required. Stimulating agriculture practises that are suitable to the respective sectors will increase agriculture production instead of increasing cultivated lands at national level and district level. A specialised team can be created focusing on studying challenges and opportunities at national and sectoral levels, by which the know-how can be the base for improving land use practices at the sectorial level.

Village level: At the village level as the smallest unit, forming a sustainable land use committee is needed under the umbrella of LUMI. The committee will discuss with different stakeholders the possible land use practices, propose sustainable activities and follow up the implementation of activities that may affect sustainable land use together with other sector officers. The power of this decentralization will enable the team to inherit sustainable land use management as culture not laws. For reforestation the degraded land, a tree nursery mostly agroforestry and fruits trees in every village through communal works (Umuganda) is proposed. For example, each villager may get 10-20 trees a year, which will enable the country to increase the planted trees and will contribute much to carbon sequestration and soil nutrients replenishment as well as being resilient with the consequences of climate change. On the other hand, organic fertilizers application is an appropriate agriculture practices for minimizing the rate of erosion and providing the buffer zones near fragile land and aquatic area to reduce sedimentation. The increase of the number of agriculture facilitators and encouraging them to apply the intercropping system will increase the land productivity instead of cultivating more areas. The integrated land use management activities through performance contract (Imihigo) for each family will raise the responsibility of every family to be in charge of sustainable land use management.

Research and academic institutions: A research institute or centre is needed to conduct studies, decentralize data, policies and plans for implementation on the ground with full stakeholder participation. Researches need to be done regarding alternative energy source, water and agriculture productivity, and urbanization plans to reduce the rate of deforestation. Research centres can build a fruitful cooperation with advanced research centres worldwide, which will help to bring on board the best available technologies and practices.

\section{Conclusions}

This study is very significant to the Government of Rwanda, land use planners, development partners and stakeholders for achieving sustainable development goals especially, goal no. 15. The change and transformation of forestland to cropland is degrading the natural ecosystem, soil structure, soil fertility and soil productivity, which has increased soil erosion. Land degradation in Rulindo District is due to the continuous agriculture practices on steep land, high rainfall together with the inappropriate soil conservations measures. The results of this study showed that there is a significant different between land uses. In regard to soil nutrients, forested land was found to have higher amount of exchangeable potassium and high organic matter while the lower values were found in the cultivated lands. On the other hand, cultivated land is subjected to have high erosion rates due to the high bulk density, which indicated poorly structure coupled with low OM content. Binding materials and low aggregate stability indicated that soil erosion was a vital issue in Rusiga District. Agroforestry trees, 
appropriate soil conservation and land fallowing were the proposed solutions for replenishing soil nutrients for achieving sustainable land management. The involvement of decision makers, policy makers, farmers, researchers, stakeholders and other development partners to sustainable land use management is needed to achieve the proposed activities.

\section{Acknowledgement}

This work would not have been possible without the assistance and support of people and institutions. We are expressing our heartfelt appreciations to Mrs. UWANYIRIGIRA Jeanine for her supervision during this study. We are giving many thanks also to the different farmers of Rusiga sector for their collaboration during data collection and its validation. We are expressing again our thanks to the support from Rwanda Education Board and the Centre for Middle Eastern Studies (CMES) at Lund University.

\section{References}

Abbasi, M. K., Khaliq, A., Shafiq, M., Kazmi, M., \& Ali, I. (2010). Comparative effectiveness of urea N, poultry manure and their combination in changing soil properties and maize productivity under rainfed conditions in Northeast Pakistan. Exp. Agric., 46, 211-230. https://doi.org/10.1017/S0014479709991050

Abbasi, M. K., \& Tahir, M. M. (2012). Economizing nitrogen fertilizer in wheat through combinations with organic manures in Kashmir, Pakistan. Agron. J., 104, 169-177. https://doi.org/10.2134/agronj2011.0264

Action pour la Protection de l'Environnement et la Promotion des Filières Agricoles (APEFA). (2017). Progress of the rational use of Yanze river water for local agriculture Development in Rulindo District and for domestic use in Kigali City project: Kigali, Rwanda.

American Society of Testing and Materials (ASTM), 1995. Annual Book of ASTM Standards, Designation D4972 - 95a: Standard Test Method for pH of Soils.

Arévalo-Gardini, E-, Canto, M., Alegre, J., Loli, O., Julca, A., \& Baligar, V. (2015). Changes in Soil Physical and Chemical Properties in Long Term Improved Natural and Traditional Agroforestry Management Systems of Cacao Genotypes in Peruvian Amazon. PLoS ONE, 10(7), e0132147. https://doi.org/10.1371/journal.pone.0132147

Armo, D. L., \& Silva, C. A. (2012). Quantification methods of carbon and organic matter in organic residues. Revista Brasileira de Ciência do Solo., 36, 1211-1220 (in Portuguese, with abstract in English).

Azeez, J. O., \& Van Averbeke, W. (2010). Nitrogen mineralization potential of three animal manures applied on a sandy clay loam soil. Bioresour. Technol., 101, 5645-5651. https://doi.org/10.1016/j.biortech.2010.01.119

Bandyopadhyay, K. K., Misra, A. K., Ghosh, P. K., \& Hati, K. M. (2010). Effect of integrated use of farmyard manure and chemical fertilizers on soil physical properties and productivity of soybean. Soil Tillage Res., 110, 115-125. https://doi.org/10.1016/j.still.2010.07.007

Bartlett, G. N., Craze, B., Stone, M. J., \& Crouch, R. (1994). Guidelines for Analytical Laboratory Safety, Department of Conservation \& Land Management, Sydney.

Benton, J. (1991). Kjeldahl Method for Nitrogen Determination: Micro-Macro Publishing, GA Athens.

Brady, N., \& Weil, R. (2002). Nitrogen and sulfur economy of soils: Helba (ed.), The Nature and properties of soils. Pearson Education, NJ.

Bucagu, C., Vanlauwe, B., \& Giller, K. E. (2013). Managing Tephrosia mulch and fertilizer to enhance coffee productivity on small holder farmers in the Eastern African highlands. Europ. J. Agronomy, 48, 19-29. https://doi.org/10.1016/j.eja.2013.02.005

Byiringiro, Fedele \& Thomas Reardon. (1996). Farm Productivity in Rwanda: Effects of Farm Size, Erosion and Soil Conservation Investments. Agricultural Economics. https://doi.org/10.1016/S0169-5150(96)01201-7

Clay, D. C., \& Lewis, L. A. (1996). Land use soil loss and sustainable agriculture in Rwanda. Human Ecology, 18(2), 147-161. https://doi.org/10.1007/BF00889179

Clay, D., Reardon, T., \& Kangasniemi, J. (1998). Sustainable intensification in the highland Tropics: Rwandan farmers' investments in land conservation and soil fertility. Economic Development and Cultural Change, 46(2), 351-377. https://doi.org/10.1086/452342

Di Gregorio, J. M. (1998). Land cover classification system: Classification Concepts and User Manual. For software version 1.0. GCP/RAF/287/ITA Africa cover - East Africa Project in cooperation with AGLS and 
SDRN. Nairobi, Rome.

Donald, P. F., Green, R. E., \& Heath, M. F. (2001). Agricultural intensification and the collapse of Europe's farmland bird populations: Proc R Soc. Lond B Biol. https://doi.org/10.1098/rspb.2000.1325

Dorigo, W. A., et al. (2015). Evaluation of the ESA CCI soil moisture product using ground-based observations. Remote Sensing of Environment, 162, 380-395. https://doi.org/10.1016/j.rse.2014.07.023

FAO, \& JRC. (2012). Global forest land-use change 1990-2005, by E.J. Lindquist,R. D’Annunzio, A. Gerrand, K. MacDicken, F. Achard, R. Beuchle, A. Brink, H.D. Eva,P. Mayaux, J. San-Miguel-Ayanz \& H-J. Stibig. FAO Forestry Paper No. 169. Food and Agriculture Organization of the United Nations and European Commission Joint Research Centre. Rome, FAO.

FAO. (2017). Sustaining the future of agriculture in the land of a thousand hills. Food and Agriculture Organization of the United Nations (FAO). Website accessed on[01/09/2017 12:58].

FAO. (2016). Food and Agriculture key to achieving the 2030 Agenda for sustainable Development- Food and Agriculture Organization of the United Nations (FAO). Website accessed on [03/10/2017 22:56]

Guidi, G. \& Hall, J. E. (1984). Effects of sewage sludge on the physical and chemical properties of soils. Pages 295305 in P. L'Hermite and H. Ott, eds. Processing and use of sewagesludge: proceedings of the 3rd international symposium.

Hansson et al. (2011). Differences in soil properties in adjacent stands of Scots pine, Norway spruce and silver birch in SW Sweden. Forest Ecology and Management, 262, 522-530. https://doi.org/10.1016/j.foreco.2011.04.021

Kagabo, D. M., Stroosnijder, L., Visser, M., \& Moore, D. (2013). Soil erosion, soil fertility and crop Yield on slow-forming terraces in the highlands of Buberuka, Rwanda. Soil tillage research, 128, 23-29. https://doi.org/10.1016/j.rse.2014.07.023

Karimi, A., \& Naderi, M. (2007). Yield and Water Use Efficiency of Forage Corn as Influenced by Superabsorbent Polymer Application in Soils with Different Textures. Agr. Res. J.(Iran). 7(3),187-198.

Mutwewingabo, B., \& Rutunga, V. (1987). Etude des sols des stations d'essai du projet PIA situés dans la Mwogo, à Gitarama, à Kaduha et dans la Vallée de l'Akanyaru. MINAGRI-PIA, Kigali.

National Institute of Statistics of Rwanda (NISR), Ministry of Finance and Economic Planning (MINECOFIN) [Rwanda]; 2012. Rwanda Fourth Population and Housing Census. Rulindo District.

Panwar, N. R., Ramesh, P., Singh, A. B., \& Ramana. S. (2010). Influence of organic, chemical, and integrated management practices on soil organic carbon and soil nutrient status under semi-arid tropical conditions in central India Commun. Soil Sci. Plant Anal., 41, 1073-1083. https://doi.org/10.1080/00103621003687166

USDA. (2017). Soil quality kit, guide for educators. National resoures conservation services. Available on https://www.nrcs.usda.gov [accessed on 03/09/2014/7].

Viollete, G., Karina, P., \& Esperanza, H. (2009). Effects of the different land use on soil che mical properties, decomposition rate and earthworm communities in tropical Mexico. Pedologia, 53.

Zhang, M., He, Z., \& Wilson, M. J. (2004). Effects of Land Use on the Chemical and Physical Properties of Red Soils. In: Wilson M.J., He Z., Yang X. (eds) The Red Soils of China. Springer, Dordrecht. https://doi.org/10.1007/978-1-4020-2138-1_19

Zingore, S., Delve, R. J., Nyamangara, J., \& Giller, K. E. (2008). Multiple benefits of manure: the key to maintenance of soil fertility and restoration of depleted sandy soils on African smallholder farms. Nutr. Cycl. Ag oecosyst. 80, 267-282.

\section{Copyrights}

Copyright for this article is retained by the author(s), with first publication rights granted to the journal.

This is an open-access article distributed under the terms and conditions of the Creative Commons Attribution license (http://creativecommons.org/licenses/by/3.0/). 